\title{
Meteorological Drought Analysis for Helmand River Basin, Afghanistan
}

\author{
Mohammad Musa ALAMI ${ }^{1}$ \\ Gokmen TAYFUR ${ }^{2}$
}

\begin{abstract}
This study evaluates drought at Lashkargah, Farah, Adraskan, and Gardandiwal stations in Helmand River Basin (HRB) in Afghanistan to determine appropriate drought indices for the basin. Thirty seven years of monthly recorded precipitation data from 1979 to 2015 are employed with different drought index (DI) methods which include the Standardized Precipitation Index (Normal-SPI, Log-SPI, and Gamma-SPI), the Percent of Normal (PN), and the Deciles. All the methods are applied to the annual long term precipitation data. The log-SPI and the gamma-SPI predict extreme drought conditions, whereas, the normal-SPI determines wet and less dry conditions. The results emphasize that the PN and the Deciles methods predict more drought years in comparison to the SPI methods. The Deciles method shows longer period of extreme and severe drought than other methods. The five methods indicate various drought intensities in 1985, 1987, 1994, 1997, 1999, 2000, 2001, 2002, 2003, and 2004 at all the stations. The extreme drought condition in 2001 at all the stations confirms to the recorded drought reports for the same region. It is noted that since the log-SPI and the gamma-SPI capture the historical extreme and severe drought periods successfully, these are recommended as the drought monitoring indices for Helmand River Basin.
\end{abstract}

Keywords: Afghanistan, deciles, drought indices, Helmand River Basin, PN, SPI.

\section{INTRODUCTION}

Drought is a natural phenomenon that adversely affects environment, agriculture, humans, wildlife, economic and social life [1,2]. Various drought indices have been developed as the drought monitoring and assessment tools in different parts of the world. Drought indices are quantitative measurements that determine drought level and intensity by integrating one or more variables of data such as precipitation and evapotranspiration into a single numerical value [3]. The widely employed drought indices are the Standardized Precipitation Index

Note:

- This paper was received on January 26, 2021 and accepted for publication by the Editorial Board on January 11, 2022.

- Discussions on this paper will be accepted by September 30, 2022.

- https://doi.org/10.18400/tekderg.868595

1 Helmand University, Department of Civil Engineering, Helmand, Afghanistan musa_afghanistan@yahoo.com - https://orcid.org/0000-0002-1478-9482

2 Izmir Institute of Technology, Department of Civil Engineering, Izmir, Turkey gokmentayfur@iyte.edu.tr - https://orcid.org/0000-0001-9712-4031 
(SPI) which is used worldwide, the Palmer Drought Severity Index (PDSI) used in the United States, the Deciles Index widely used in Australia, the China-Z Index (CZ) used in China, and the Percent of Normal (PN).

There are many new indices that have been developed since early 2000s using not only precipitation but also soil moisture, snow, and evaporation effects, such as the RDI (Reconnaissance Drought Index developed by [4])), the Non-Stationary RDI [5]), the SPEI (the standardized precipitation evapotranspiration index, [6]), among many. Mishra and Singh [7] and Eslamian et al. [8] have reviewed the mostly employed drought indices, together with their advantages and limitations. Bulut and Y1lmaz [9] have carried out drought analysis for Turkey using the remote sensing hydrological and vegetation cover data. Keskiner et al [10] have investigated drought effects on ponds in Seyhan River Basin. Dikici and Aksel [11] have employed two different drought indices (Normalized Difference Vegetation Index (NDVI) and Vegetation Condition Index (VCI)) to assess drought at Asi River Basin. Mehr et al [12] have employed the wavelet-packet-genetic programming meteorological drought tool and performed application at two stations in Ankara province. Dikbas and Bacanli [13] have used the SPI for the assessment of drought at 13 stations in the central Anatolia. In Afghanistan, other than precipitation, there are no available data on other hydrological variables such as evaporation, snow, soil moisture etc. Therefore, this study has employed drought indices requiring only precipitation data.

Although Afghanistan has suffered drought for the last three decades, there is no substantial scientific research that has evaluated the drought conditions due to lack of meteorological data. Nevertheless, there are some reports that mention historical drought conditions in Afghanistan. The World Bank Working Paper by Ahmad and Wasiq [14] indicates four consecutive years of drought from 1998 to 2001 in Afghanistan. Mayan [15] cites the unusual droughts in 1995-2001 in Afghanistan until heavy snow in 2002-2003 winter season. Another scientific project report by the Asia-Pacific Network for Global Change Research [16] states the worst drought in 2001 in its recorded history of Afghanistan.

There are also some articles that have investigated drought conditions in neighboring countries of Iran and Pakistan. Ashraf and Routray [17] point out the most severe drought years of 2000, 2001, 2002, and 2004 in province of Balochistan province of Pakistan. A study by Zarei et al. [1] in bordering city of Saravan, Iran, indicates extreme droughts in 1987, 1998, 2010, and 2001. Morid et al. [18] have states that the most recent drought of 19982001 in Iran has been the worst for the last three decades.

This study aims to evaluate the performance of several drought indices to find the most appropriate one(s) for monitoring droughts in Helmand River Basin of Afghanistan. The Normal-SPI, the log-SPI, the gamma-SPI, PN, and the Deciles are employed since they require only precipitation data.

\section{STUDY AREA AND DATA}

\subsection{Study Area}

Afghanistan is a land-locked country with a total area of $652000 \mathrm{~km}^{2}$ in the south central Asia with geographic location of $3300 \mathrm{~N}, 6500 \mathrm{E}$. The climate is arid to semi-arid with cold winters and hot summers [19]. Afghanistan is divided into five major river basins as Amu 
Darya River Basin, Harirud-Murghab River Basin, Helmand River Basin, and Kabul River Basin (Figure 1).

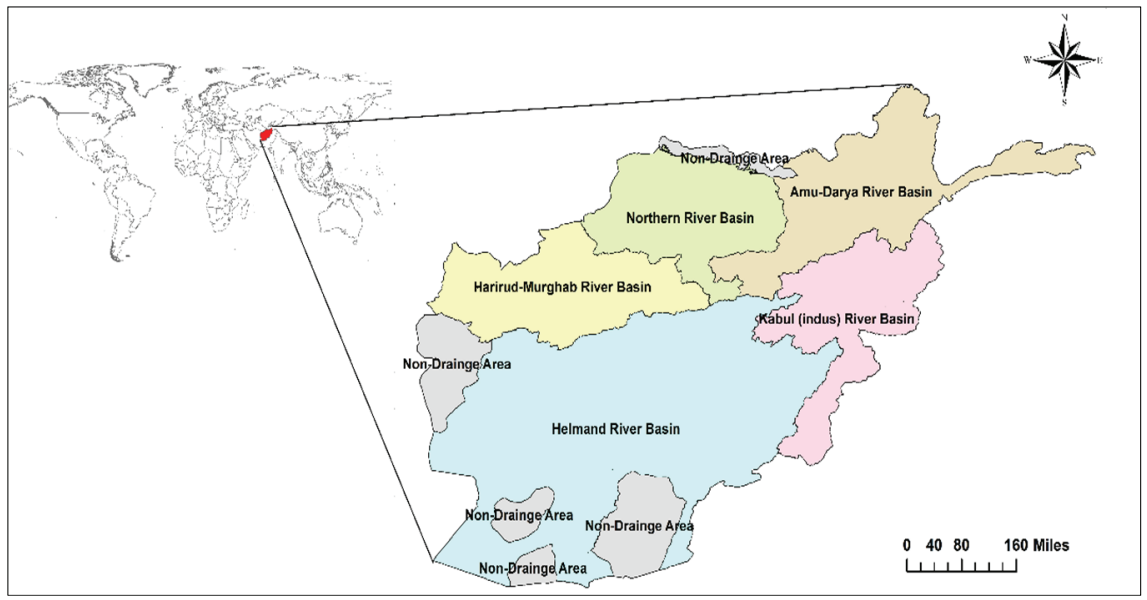

Figure 1 - Five major river basins of Afghanistan

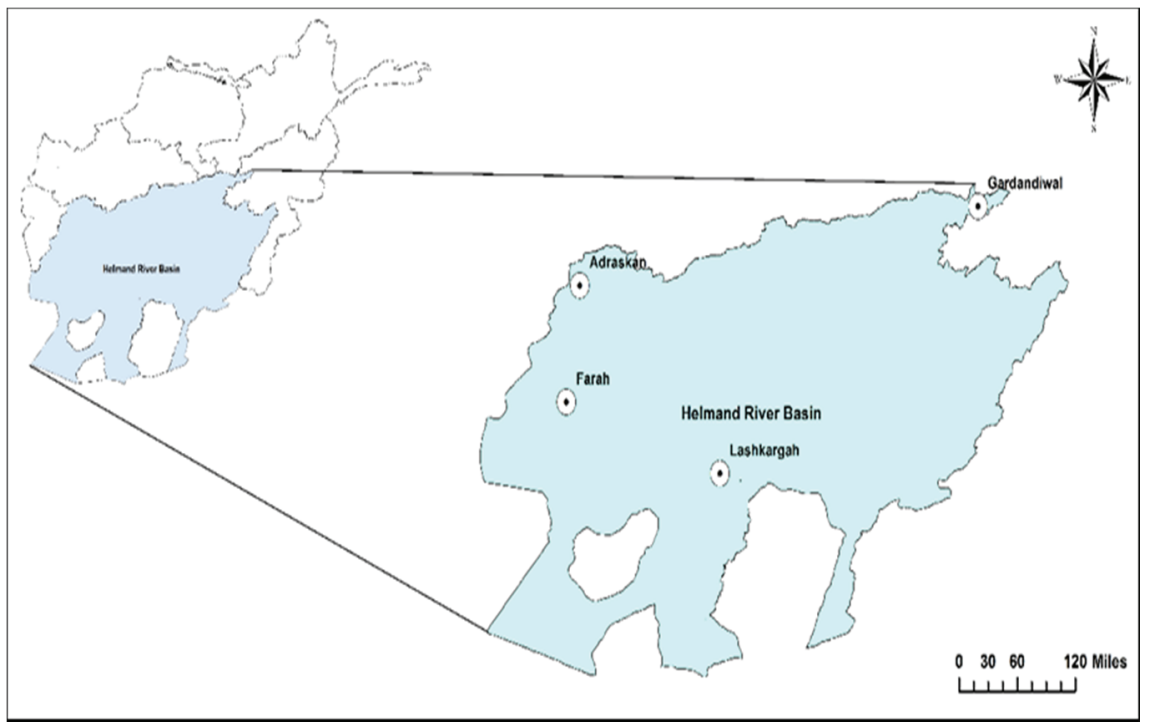

Figure 2 - Helmand River Basin and four precipitation stations

The study area is Helmand River Basin (HRB) which is also known as Hirmand River Basin. It is the largest basin among the five basins in Afghanistan (Figure 2) and has a total area of $345200 \mathrm{~km}^{2}$, of which $82.2 \%$ is located in Afghanistan [20]. The basin covers the catchment area for Helmand River, which is the longest river in Afghanistan with 1300 km length [21]. 
Helmand River originates from Hindu Kush Mountains in the north-east of Afghanistan and drains into Sistan Depression near to the Afghan-Iranian border in the south-east of Afghanistan. The annual mean precipitation varies from about $50 \mathrm{~mm}$ in the southwest to almost $300 \mathrm{~mm}$ in the northwest part of the basin [22]. Precipitation mostly happens in winter months (December, January, February, and March) and falls as snow in the upper basin.

\subsection{Data}

Due to four decades of war and conflict in Afghanistan, there have been gaps in the meteorological data. Recently, the missing precipitation data have been completed for the meteorological stations of Afghanistan by the Ministry of Energy and Water of Afghanistan (MEW). The data used in this study are obtained from the MEW for the four stations of Helmand River Basin, namely Lashkargah (3134'58.36"N-64²1'17.12"E), Farah

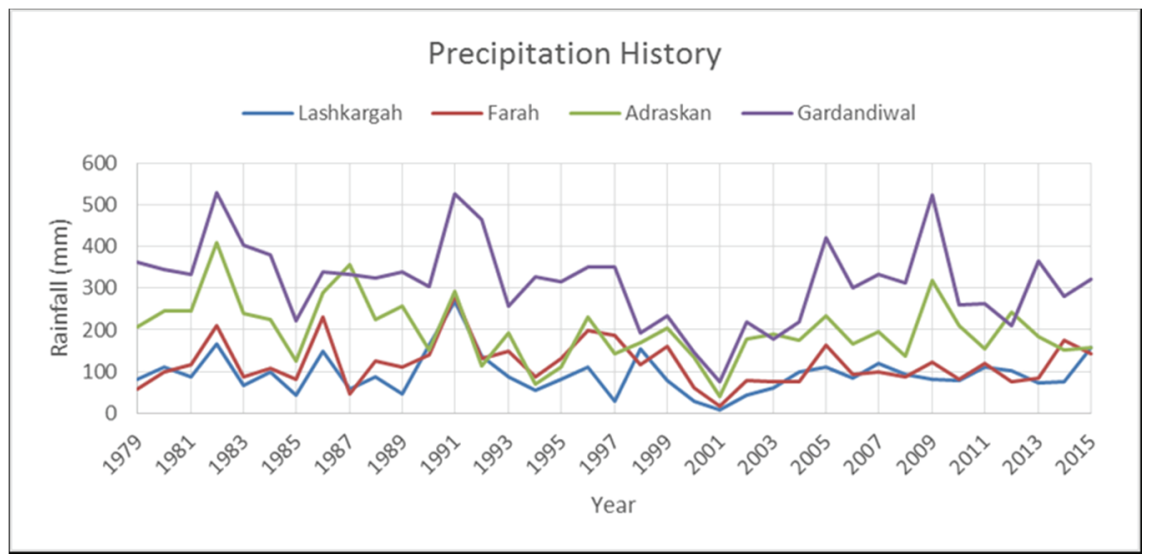

Figure 3 - Monthly recorded precipitation data for the stations

Table 1 - Rainfall characteristics at the meteorological stations

\begin{tabular}{ccccc}
\hline Rainfall characteristics & Lashkargah & Farah & Adraskan & Gardandiwal \\
\hline Mean $(\mathrm{mm})$ & 94 & 119 & 199 & 315 \\
Standard deviation $(\mathrm{mm})$ & 59 & 66 & 78 & 91 \\
Variance $(\mathrm{mm})$ & 3481 & 4356 & 6084 & 8281 \\
Kurtosis & -0.85 & -0.43 & -0.012 & -0.0098 \\
Skewness & 0.65 & 0.59 & 0.46 & 0.24 \\
Range $(\mathrm{mm})$ & 287.3 & 307.1 & 365.7 & 466.2 \\
Minimum $(\mathrm{mm})$ & 21.6 & 30.7 & 38.5 & 66.4 \\
Maximum $(\mathrm{mm})$ & 308.9 & 337.8 & 404.2 & 532.6 \\
\hline
\end{tabular}




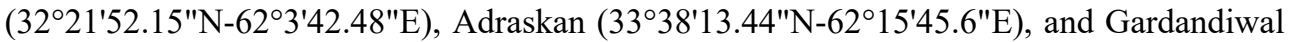
$\left(34^{\circ} 30^{\prime} 1.35^{\prime \prime} \mathrm{N}-68^{\circ} 12^{\prime} 45.56^{\prime \prime} \mathrm{E}\right)$, as shown in Figure 2. Thirty seven years (1979-2015) annual precipitation data used for the analysis are shown in Figure 3. The annual mean precipitation for Lashkargah, Farah, Adraskan, and Gardandiwal stations are 94 mm, 119 mm, 199 mm, and $315 \mathrm{~mm}$, respectively. Table 1 summarizes the rainfall characteristics for each station.

\section{METHODOLOGY}

In this study, the normal-SPI, the log-SPI, the gamma-SPI, the PN, and the Deciles methods are applied to evaluate the meteorological drought at the four stations in Helmand River Basin in Afghanistan to find the appropriate one(s) for the basin.

\subsection{Standardized Precipitation Index}

The SPI method is developed by McKee et al. [23]. Precipitation is the only input parameter for the SPI and it requires transformation of original data to the normal distribution. The mean of the transformed data series becomes zero with a standard deviation of 1 . The drought classification by the z-score index for the normal-SPI, the log-SPI and the gamma-SPI is shown in Table 2. Positive SPI values indicate wet periods, conversely negative SPI values indicate dry periods. This study has employed the normal-SPI, the log-SPI and the gammaSPI [24].

Table 2 - Drought classification for SPI values [25]

\begin{tabular}{lc}
\hline SPI value(z-score) & Drought Classification \\
\hline 2.00 or more & Extremely wet \\
1.50 to 1.99 & Very wet \\
1.00 to 1.49 & Moderately wet \\
0.99 to -0.99 & Near normal \\
-1.00 to -1.49 & Moderate drought \\
-1.50 to -1.99 & Severe drought \\
-2.00 or less & Extreme drought \\
\hline
\end{tabular}

\subsubsection{Normal-SPI}

The normal-SPI method uses the normal probability distribution instead of the gamma distribution [26]. It is mathematically easier to calculate. In this case, the SPI index simply becomes: 
$S P I=z=\frac{x-\mu}{\sigma}$

where; $z$ is the standardized value (the SPI value), $x$ is a value in the data series, $\mu$ is the mean of the data series, and $\sigma$ is the standard deviation of the data series.

\subsubsection{Log-SPI}

The log-SPI distribution is non-negative and positively skewed. It is simple and just a logarithmic transformation of data. By applying the log-normal distribution with the sample mean of logarithmic transformed data, the SPI becomes:

$S P I=z=\frac{\ln (x)-\mu}{\sigma}$

Note that $\mu$ and $\sigma$ are the mean and the standard deviation of the log-data series, respectively.

\subsubsection{Gamma-SPI}

The gamma-SPI is the most widely applied observational method for precipitation data. It involves fitting of a gamma probability density function to a given time series of precipitation data [26]. It is defined by its probability density function as [26]:

$g(x, \alpha, \beta)=\frac{1}{\beta^{\alpha} \Gamma(\alpha)} x^{\alpha-1} e^{\frac{-x}{\beta}}$

where $\alpha$ is a shape parameter greater than zero, $\beta$ is a scale parameter greater than zero, and $x$ is the amount of precipitation greater than zero. $\Gamma(\alpha)$ is the gamma function, which is defined as follows [26]:

$\Gamma(\alpha)=\int_{0}^{\infty} x^{\alpha-1} e^{-x} d x$

$\alpha$ and $\beta$ parameters can be estimated as follows [27]:

$\alpha=\frac{1}{4 A}\left(1+\sqrt{1+\frac{4 A}{3}}\right)$

$\beta=\frac{\bar{x}}{\alpha}$

$A=\ln (\bar{x})-\frac{\sum \ln (x)}{n}$

In Eq. (7), $n$ is the number of observations. $\bar{x}$ is the mean value of the precipitation data. After estimating $\alpha$ and $\beta$ coefficients, the probability density function is integrated with 
respect to $x$, which yields the following expression $G(x)$ for the cumulative probability distribution function [26]:

$G(x)=\int_{0}^{x} g(x) d x=\frac{1}{\beta^{\alpha} \Gamma(\alpha)} \int_{0}^{x} x^{\alpha-1} e^{-x / \beta} d x$

Substituting $t$ for $x / \beta$ in Eq. (8) yields to [26]:

$G(x)=\frac{1}{\Gamma(\alpha)} \int_{0}^{x} t^{\alpha-1} e^{-t} d t$

As the gamma function is not defined for $\mathrm{x}=0$, for possibility of zero values, the cumulative probability function becomes [26]:

$H(x)=q+(1-q) G(x)$

where $q$ is the probability of zero precipitation. This cumulative probability distribution is then transformed into the standard normal distribution to yield the SPI. The approximate conversion provided by Abramowitz and Stegun [28] is given as follows:

for $0<H(x)<0.5$

$z=S P I=-\left(t-\frac{c_{0}+c_{1} t+c_{2} t^{2}}{1+d_{1} t+d_{2} t^{2}+d_{3} t^{3}}\right), t=\sqrt{\ln \left(\frac{1}{(H(x))^{2}}\right)}$

for $0.5<H(x)<1.0$

$z=S P I=+\left(t-\frac{c_{0}+c_{1} t+c_{2} t^{2}}{1+d_{1} t+d_{2} t^{2}+d_{3} t^{3}}\right), t=\sqrt{\ln \left(\frac{1}{(1.0-H(x))^{2}}\right)}$

where $c_{0}=2.515517, c_{1}=0.802853, c_{2}=0.010328, d_{1}=1.432788, d_{2}=0.189269$, and $d_{3}=0.001308$

\subsection{Percent of Normal}

The PN method is a drought index for the evaluation of meteorological data as the percent actual precipitation percent of the normal precipitation. It is generally applied to long-term mean precipitation data where at least a 30 -year mean is considered [18, 21]. PN values of $80 \%-120 \%$ indicate normal conditions while values less than $80 \%$ indicate dry periods. Drought index classification for the PN values is shown in Table 3. Note that the literature recommends to employ the PN method together with other drought indices for healthy predictions [29]. 
Table 3 - Drought index classification for PN [21]

\begin{tabular}{lc}
\hline NP values & Drought Classification \\
\hline $180 \%$ or more & Extremely wet \\
$161 \%$ to $180 \%$ & Very wet \\
$121 \%$ to $160 \%$ & Moderately wet \\
$81 \%$ to $120 \%$ & Near normal \\
$41 \%$ to $80 \%$ & Moderate drought \\
$21 \%$ to $40 \%$ & Severe drought \\
$20 \%$ or less & Extreme drought \\
\hline
\end{tabular}

\subsection{Deciles}

The Deciles approach is developed by Gibbs and Maher [30]. By this method, long-term monthly precipitation is ranked from the highest to the lowest to construct a cumulative frequency distribution. The distribution is divided into ten parts (Deciles) on the basis of equal probabilities [26]. The first Decile is the precipitation value not exceeded by the lowest $10 \%$ of all the precipitation values in a record. The second Decile is in between the lowest $10 \%$ and $20 \%$, etc. The Deciles are grouped into five classes as two Deciles per class. If a precipitation falls into the lowest $20 \%$ (Deciles 1 and 2), it is classified as the much below normal, corresponding to the extreme drought condition. Deciles 3 to 4 (20 to $40 \%$ ) indicate the below normal precipitation, corresponding to the severe drought. Deciles 5 to 6 (40 to $60 \%$ ) indicate the near normal precipitation (normal condition), Deciles 7 and 8 (60 to 80\%) indicate the above normal precipitation (very wet condition) and Deciles 9 and 10 (80 to $100 \%$ ) indicate the much above normal precipitation (extremely wet condition) Morid et al. [18]. The Deciles values and the drought ranking classifications are given in Table 4. As seen, the Deciles ranking indicates two drought intensities as the below normal (severe drought) and the much below normal (extreme drought).

Table 4 - Deciles drought ranking classification

\begin{tabular}{lc}
\hline Deciles values & Drought Classification \\
\hline Deciles 1-2 (lowest 20\%) & Much below normal (extreme drought) \\
Deciles 3-4 (next lowest 20\%) & Below normal (severe drought) \\
Deciles 5-6 (middle 20\%) & Near normal \\
Deciles 7-8 (next highest 20\%) & Above normal (very wet) \\
Deciles 9-10 (highest 20\%) & Much above normal (extremely wet) \\
\hline
\end{tabular}




\section{RESULTS}

The SPI (Normal-SPI, Log-SPI, and Gamma-SPI), the PN, and the Deciles values are computed for Lashkargahm, Farah, Adraskan, and Gardandiwal stations of Helmand River Basin in Afghanistan.

\subsection{Lashkargah Station}

According the SPI results for Lashkargah station (Figure 4), all the methods provide almost the same results except for years 1991 and 2001. The normal-SPI makes higher wet prediction for 1991 while it underestimates the drought in 2001. The log-SPI and the gammaSPI methods predict the extreme drought in 2001 which is the worst drought in its recorded history of Afghanistan [14, 15, 16]. The extreme and severe drought conditions happened in 1997 and 2000 are also predicted by all the methods, except the normal-SPI. Moderate drought years include 1985, 1989 and 2002 while the extreme wet periods are 1990, 1991 and 1992. The severe and moderate wet years include 1982, 1986 and 1998.

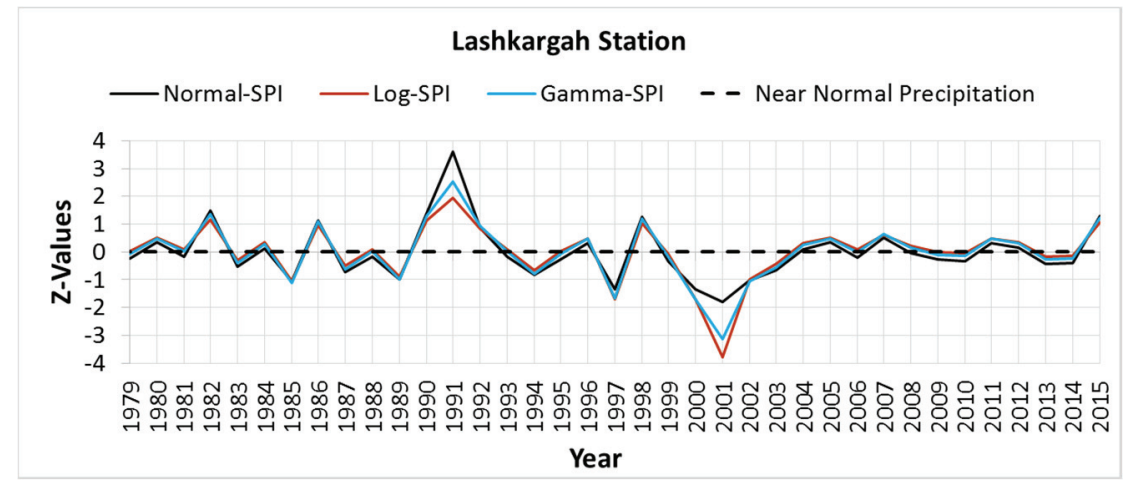

Figure 4 - SPI results for Lashkargah station

Table 5 - Deciles result for all the stations

\begin{tabular}{|c|c|c|c|c|}
\hline \multicolumn{4}{|c|}{ Annual Rianfall Values (mm/year) } & \multirow{2}{*}{ Classification } \\
\hline Lashkargah & Farah & Adraskan & Grandandiwal & \\
\hline $44.22-60.19$ & $69.45-79.59$ & $121.72-144.59$ & $203.97-224.95$ & $\begin{array}{c}\text { Much below } \\
\text { normal (extreme } \\
\text { drought) }\end{array}$ \\
\hline $74.68-81.59$ & $87.65-94.68$ & $157.44-176.56$ & $262.23-306.81$ & $\begin{array}{c}\text { Below normal } \\
\text { (severe drought) }\end{array}$ \\
\hline $86.53-95.53$ & $109.72-120.78$ & $192.19-209.74$ & $323.25-333.39$ & Near normal \\
\hline $110.42-118.01$ & $133.75-158.37$ & $232.01-243.67$ & $346.92-365.74$ & $\begin{array}{c}\text { Above normal } \\
\text { (very wet) }\end{array}$ \\
\hline $155.85-168.83$ & $191.64-282.39$ & $290.78-409.71$ & $438.74-527.82$ & $\begin{array}{c}\text { Much above } \\
\text { normal } \\
\text { (extremely wet) }\end{array}$ \\
\hline
\end{tabular}


The Deciles results and threshold ranges for Lashkargah Station are given in Table 5. When precipitation is less than $81.6 \mathrm{~mm} /$ year and $60.2 \mathrm{~mm} /$ year, the severe and extreme droughts occur, respectively. Figure 5 shows the Deciles ranking for Lashkargah station. As compared to the SPI results, the Deciles ranking indicates long extreme and severe drought conditions. Extreme drought years are 1985, 1987, 1989, 1994, 1997, 2000, 2001 and 2002. The severe drought years are 1983, 1999, 2003, 2009, 2010, 2013 and 2014. According to the Deciles method, the extreme wet conditions include 1982, 1986, 1990, 1991, 1992, 1998 and 2007.

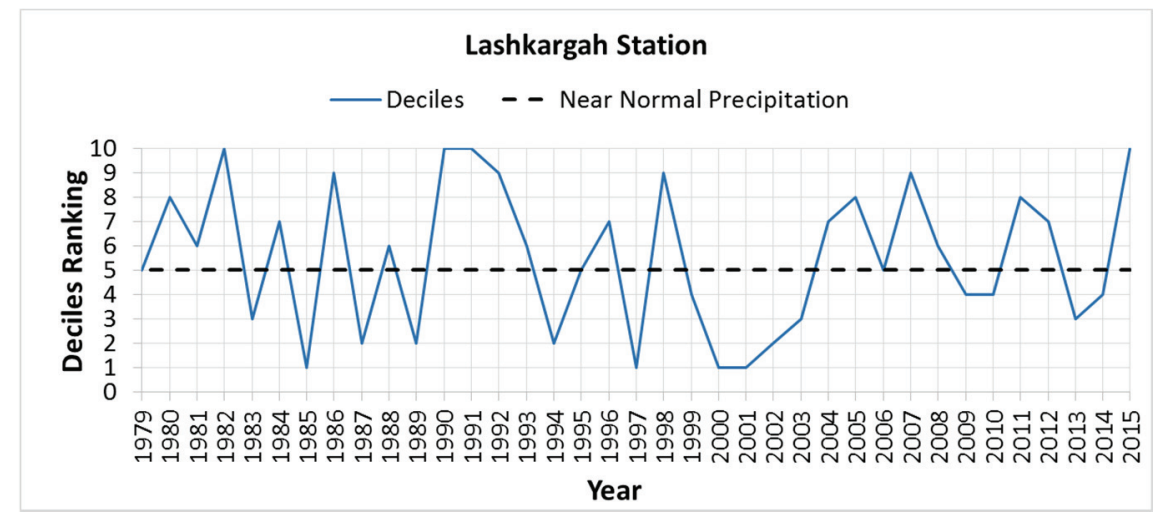

Figure 5 - Deciles ranking for Lashkargah station

Figure 6 presents the results for the PN method for Lashargah station. This method indicates the extreme and severe droughts in 1997, 2000 and 2001. The moderate droughts include 1983, 1985, 1987, 1989, 1994, 2010, 2013 and 2014. According to this index, the extreme wet periods are 1990, 1991 and 1992. The severe and moderate wet years are 1982, 1986 1998 and 2007.

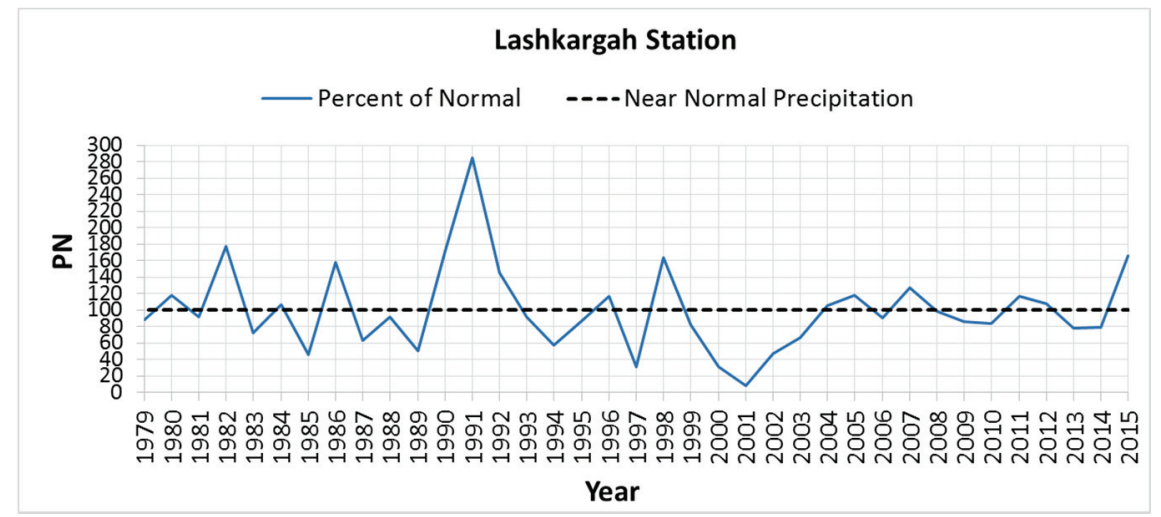

Figure 6 - PN results for Lashkargah station 


\subsection{Farah Station}

As presented in Figure 7, all the methods provide almost the same results except for the years of 1991 and 2001. The normal-SPI makes slightly higher wet prediction for 1991 while it underestimates the drought condition in 2001. The log-SPI and the gamma-SPI methods make the extreme drought prediction for 2001 while the normal SPI makes this prediction as the severe drought. The extreme wet conditions include 1986, and 1991 while the moderate and severe wet years are 1982, 1996 and 1997.

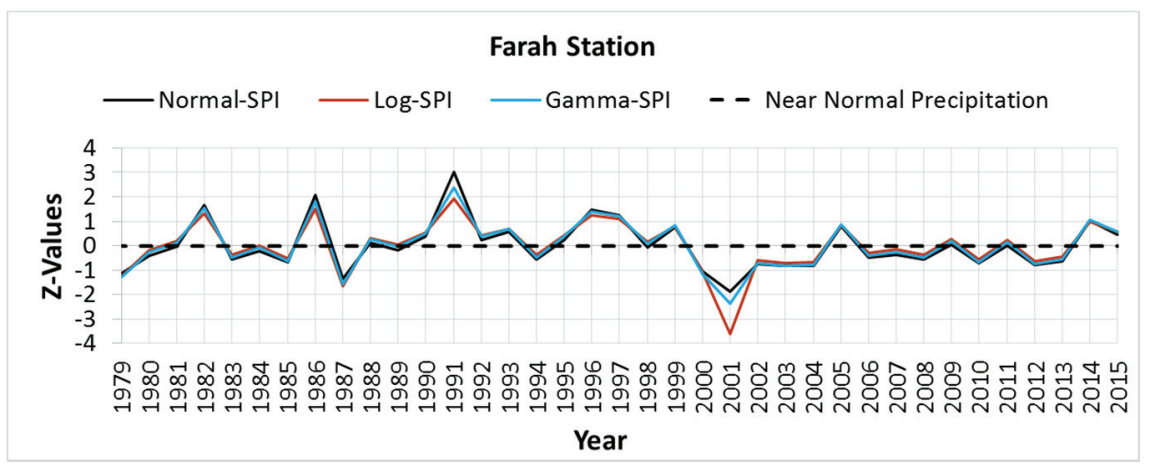

Figure 7 - SPI results for Farah station

The Deciles results and threshold ranges for Farah station are given in Table 5. When the precipitation is less than $94.6 \mathrm{~mm} /$ year and $79.6 \mathrm{~mm} / \mathrm{year}$, the severe and extreme drought conditions occur, respectively. Figure 8 shows the deciles ranking for this station. As compared to the SPI results, the Deciles make more extreme and severe drought predictions. The extreme drought years include 1979, 1987, 2000, 2001, 2002, 2003, 2004 and 2012. The severe drought years are 1983, 1985, 1994, 2006, 2008, 2010 and 2013. According the Deciles index, the extreme wet conditions are 1982, 1986, 1991, 1996, 1997, 1999 and 2014.

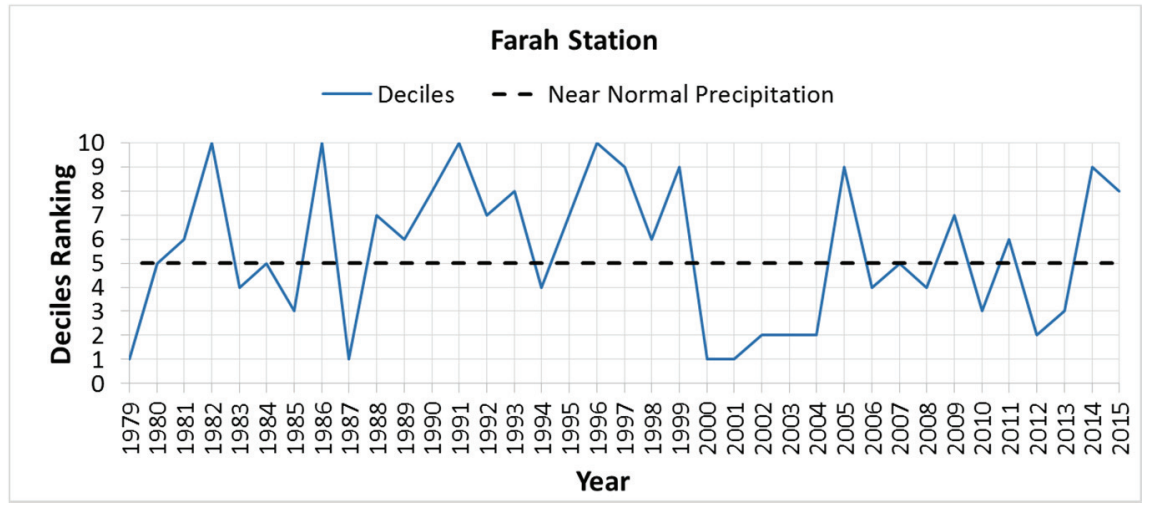

Figure 8 - Deciles ranking for Farah station 
Figure 9 shows the results for the PN method for Farah station. This method indicates the extreme drought in 2001 and severe drought in 1987. The moderate drought years are 1979, 1980, 1983, 1985, 1994, 2000, 2002, 2003 and 2014. This method specifies the extreme wet periods as 1986 and 1991. The severe and moderate wet years are 1982, 1993, 1996, 1997 , 1999, 2005 and 2014.

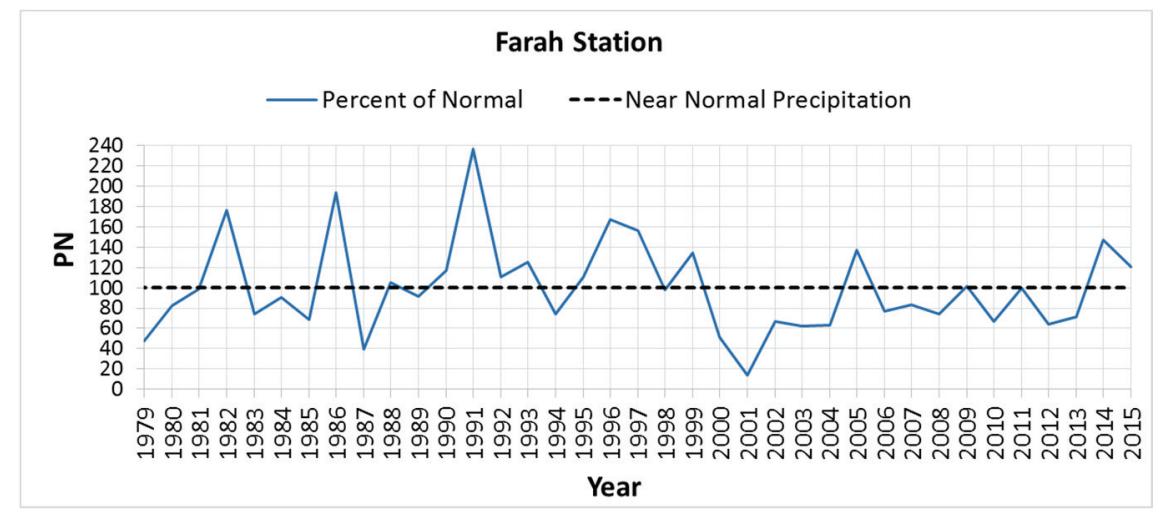

Figure 9 - PN results for Farah station

\subsection{Adraskan Station}

Figure 10 shows that the normal-SPI and the gamma-SPI indicate almost the same results for Adraskan station and the log-SPI predicts the extreme drought condition in 2011. According the SPI results at Adraskan station, the extreme and severe drought years are 1994 and 2001. Moderate drought years include 1985, 1992, 1995 and 2000. The extreme wet periods are 1982 and 1987 while the severe and moderate wet years include 1986 and 2009.

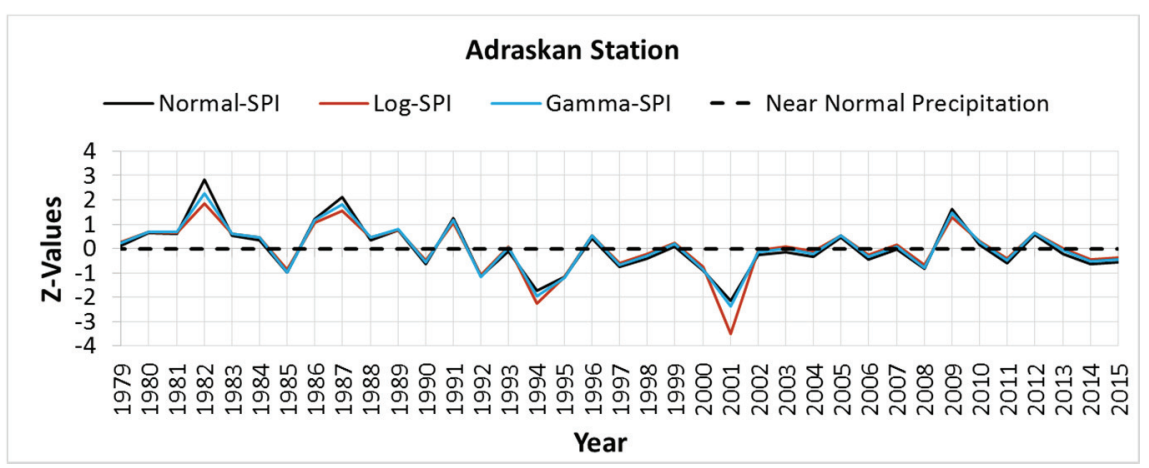

Figure 10 - SPI results for Adraskan station 
The Deciles results and threshold ranges for this station are given in Table 5. When precipitation is less than $176.6 \mathrm{~mm} /$ year and $144.6 \mathrm{~mm} /$ year the severe and extreme droughts occur, respectively. Figure 11 shows the Deciles ranking for Adraskan station. The comparison of the Deciles results against those of the SPI indicates more extreme and severe drought conditions. Extreme drought years are 1985, 1992, 1989, 1994, 1995, 1997, 2000, 2001 and 2008. The severe drought years are 1990, 1998, 2004, 2006, 2011, 2014 and 2015. According to the Deciles method, the extreme wet condition years are 1980, 1981, 1982, 1986, 1987, 1991 and 2009.

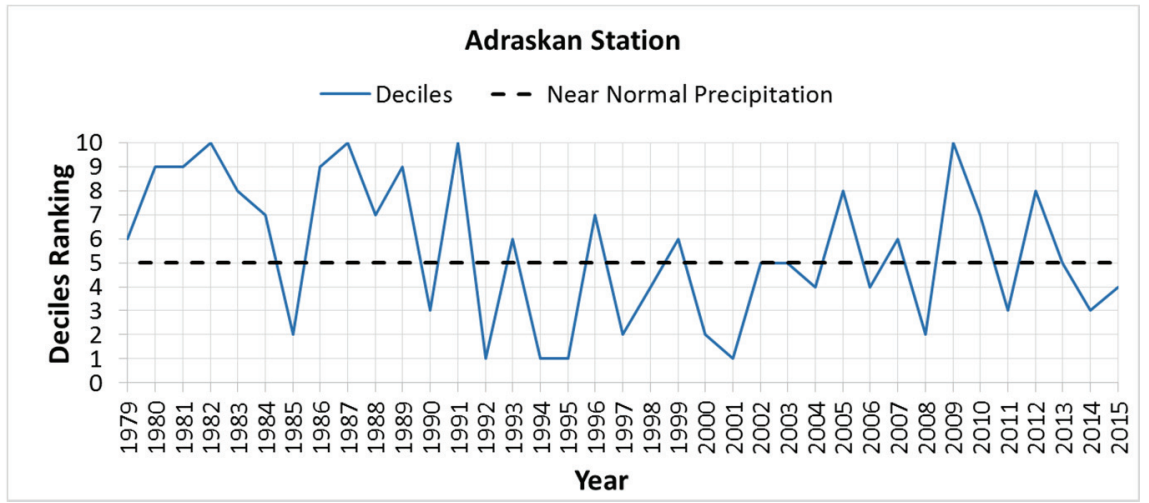

Figure 11 - Deciles ranking for Adraskan station

The results for the PN method are given in Figure 12 for Adraskan station. The PN method indicates the extreme drought condition in 2001 and severe drought in 1994. The moderate drought conditions are 1985, 1990, 1992, 1994, 1995, 1997, 2000, 2006, 2008, 2011 and 2014. This method specifies the extreme and severe wet periods in 1982 and 1987. The moderate wet years are 1980, 1981, 1986, 1989, 1991, 2009 and 2012.

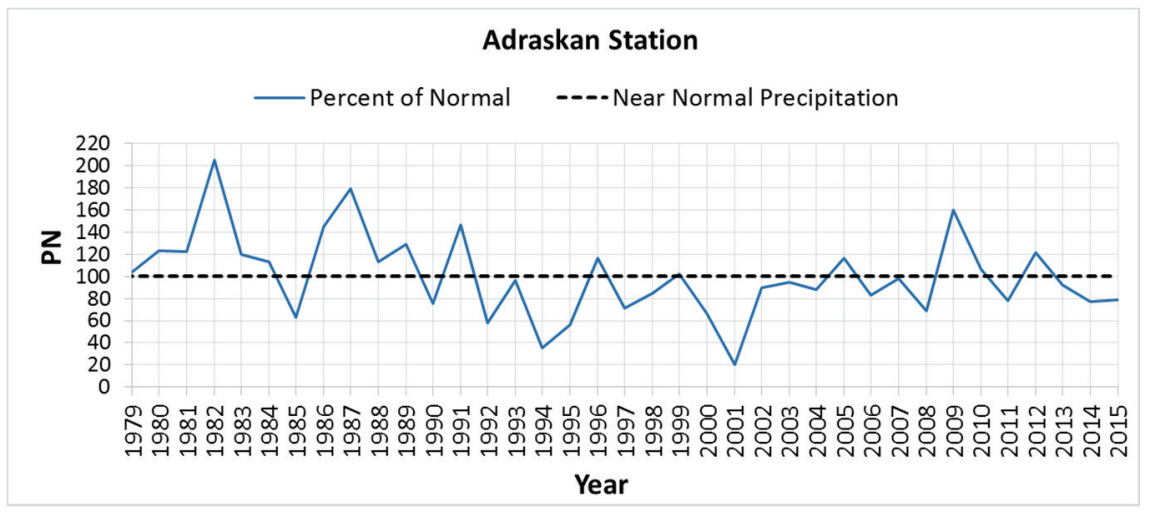

Figure 12 - PN results for Adraskan station 


\subsection{Gardandiwal Station}

Figure 13 shows the results of the SPI method for Gardandiwal station. According to the results, the normal-SPI tends to show the wet and less drought conditions. Conversely, the log-SPI and the gamma-SPI predict the extreme drought conditions. The log-SPI and the gamma-SPI results in this station indicate the extreme drought conditions in years 2000 and 2001, but the normal-SPI shows the extreme drought condition only in 2001 and the severe drought in 2000. All the SPI methods show the same moderate drought conditions at this station in 1985, 1998, 1999, 2002, 2003, 2004 and 2012. The extreme wet years are 1982, 1991 and 2009 while the moderate and severe wet years include 1992 and 2005.

The Deciles results and the threshold ranges for Gardandiwal station are given in Table 5. When precipitation is less than $306.8 \mathrm{~mm} /$ year and $224.9 \mathrm{~mm} /$ year the severe and extreme drought conditions have occurred, respectively. Figure 14 shows the Deciles ranking for this station. The comparison of the Deciles ranking with the SPI results indicates more extreme and severe drought conditions. The extreme drought conditions include 1985, 1998, 2000, 2001, 2002, 2003, 2004 and 2012. The severe drought years are 1990, 1993, 1999, 2006, 2010, 2011 and 2014. Based on the results of the Deciles, the extreme wet conditions include 1982, 1983, 1984, 1991, 1992, 2005, 2009 and 2013.

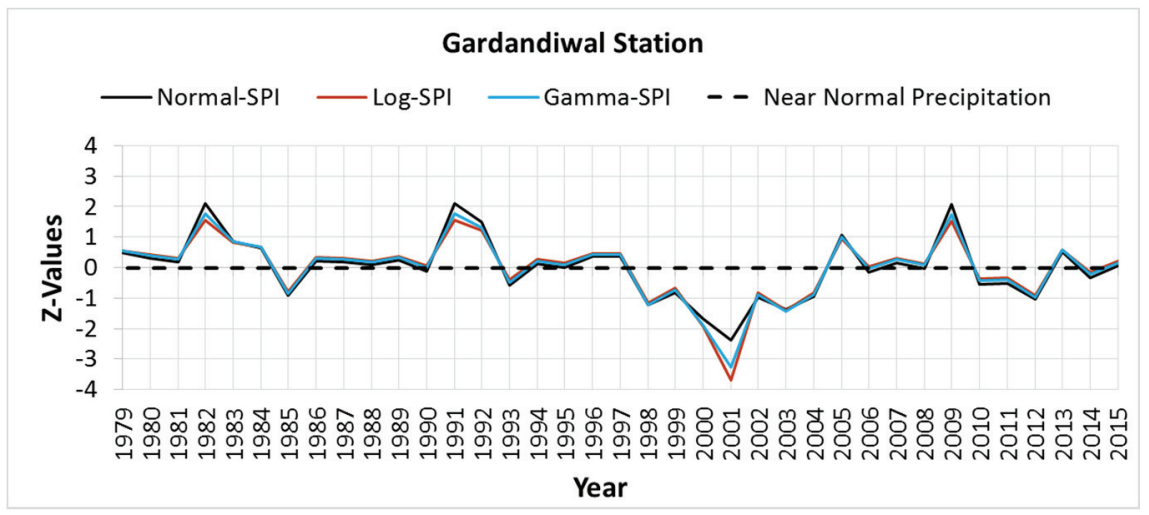

Figure 13 - SPI results for Gardandiwal station

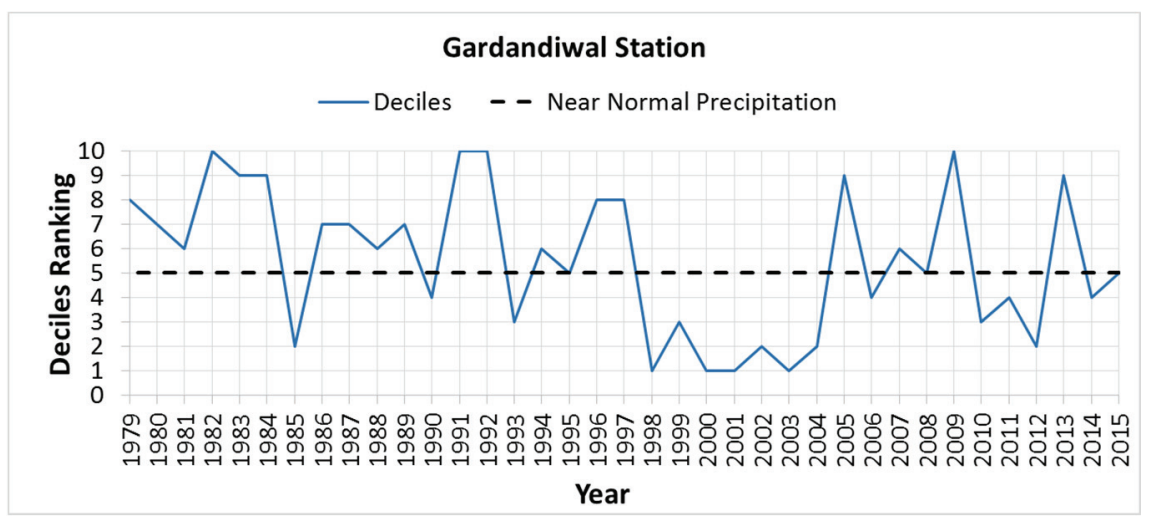

Figure 14 - Deciles ranking for Gardandiwal station 
The results for the PN method are given in Figure 15 for Gardandiwal station. The PN does not indicate the extreme drought condition for this station. The PN shows the severe drought in 2001. The moderate drought years are 1985, 1993, 1998, 1999, 2000, 2002, 2003, 2004 and 2012. This method specifies the very wet period as 1982, 1991 and 2009 while the moderate wet years include 1983, 1984, 1992 and 2005.

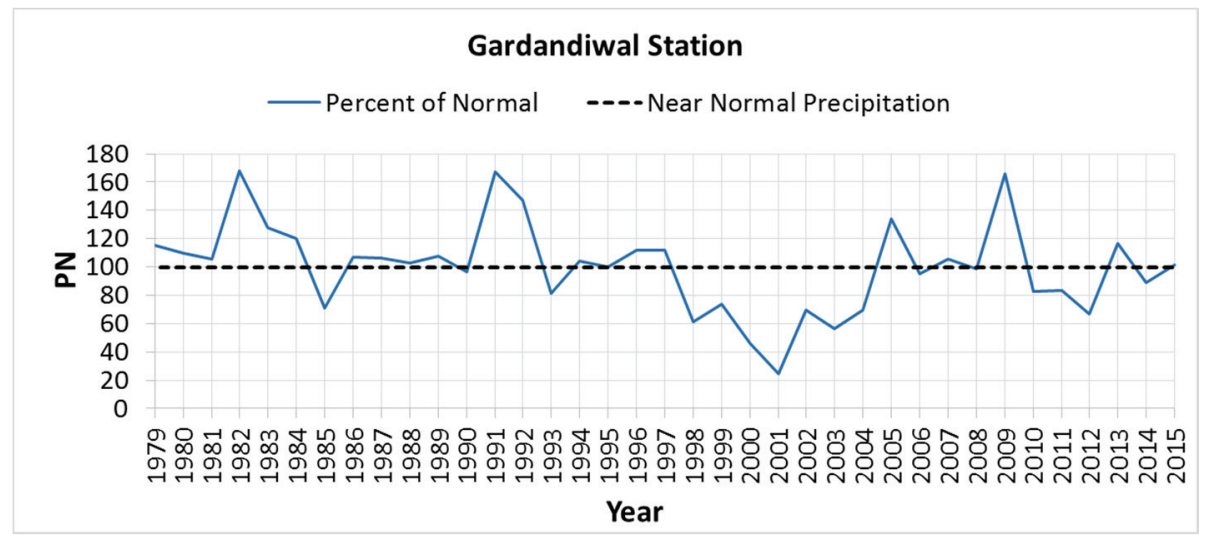

Figure 15 - PN results for Gardandiwal station

\section{DISCUSSIONS ON THE RESULTS}

Table 6 summarizes the drought intensities for the stations. The extreme, severe, and moderate drought intensities are listed for the normal-SPI, the log-SPI, the gamma-SPI, and the PN methods. The moderate drought intensity is not listed for the Deciles method because this method just indicates the extreme and severe droughts.

According to the results of all the methods, the common extreme drought year is found to be 2001 for all the stations. Year 2000 is also generally predicted as the extreme drought year for Gardandiwal station and 1994 for Adraskan station. Years 1997 and 2000 are predicted as the severe drought years for Lashkargah station and 1987 for Farah station. The common moderate drought conditions are observed as 1985 and 2002. As discussed before in Figures 4-15, the extreme wet conditions are also generally common for all the stations in 1982, 1991, and 1992. Therefore, all the stations seem to have experienced almost the same occurrences of the drought and wet conditions. The results indicate that the PN method overpredicts the number of moderate drought years as opposed to the SPI methods. Since the Deciles ranking indicates two drought intensities as the severe, and the extreme, this method predicts more years of the extreme and severe droughts than the other methods (see Table 6).

These results confirm the reports $([14,15,16])$ about Afghanistan's droughts during the last three decades. As discussed earlier, the extreme droughts in the central and southwestern parts of Afghanistan and neighboring regions of the study area in Iran and Pakistan, occurred mostly in between 1998 and 2002 with the peak in 2001, are reported elsewhere $[15,17,18]$. 
Table 6 - Summary of the indicated historical droughts by the five DI methods

\begin{tabular}{|c|c|c|c|c|c|c|c|c|c|c|c|c|c|c|}
\hline \multirow{4}{*}{ Stations } & \multicolumn{14}{|c|}{ Methods } \\
\hline & \multicolumn{3}{|c|}{ Normal-SPI } & \multicolumn{3}{|c|}{ Log-SPI } & \multicolumn{3}{|c|}{ Gamma-SPI } & \multicolumn{3}{|c|}{ Percent of Normal } & \multicolumn{2}{|c|}{ Deciles } \\
\hline & \multicolumn{14}{|c|}{ Drought Intensity } \\
\hline & 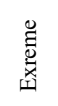 & 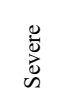 & $\begin{array}{l}\frac{0}{\pi} \\
\frac{\pi}{0} \\
\frac{\pi}{\Delta} \\
\Sigma\end{array}$ & 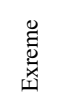 & $\begin{array}{l}0 \\
\stackrel{0}{0} \\
\stackrel{0}{0}\end{array}$ & $\begin{array}{l}\frac{0}{\pi} \\
\frac{\pi}{0} \\
\frac{\pi}{0} \\
\Sigma\end{array}$ & 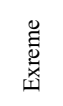 & $\begin{array}{l}\stackrel{0}{0} \\
\text { Dे } \\
\ddot{D}\end{array}$ & $\begin{array}{l}\frac{\pi}{\pi} \\
\frac{\pi}{0} \\
\frac{0}{\Sigma}\end{array}$ & 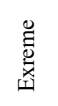 & $\begin{array}{l}\stackrel{\Xi}{0} \\
\vec{J} \\
\tilde{D}\end{array}$ & $\begin{array}{l}\frac{\pi}{\pi} \\
\stackrel{\Xi}{0} \\
\sum\end{array}$ & 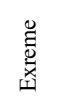 & 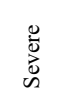 \\
\hline Lashkargah & - & 2001 & $\begin{array}{l}1985 \\
1989 \\
1997 \\
2000 \\
2002\end{array}$ & 2001 & $\begin{array}{l}1997 \\
2000\end{array}$ & $\begin{array}{l}1985 \\
1989 \\
2002\end{array}$ & 2001 & $\begin{array}{l}1997 \\
2000\end{array}$ & $\begin{array}{l}1985 \\
1989 \\
2002\end{array}$ & 2001 & $\begin{array}{l}1997 \\
2000\end{array}$ & $\begin{array}{l}1983 \\
1985 \\
1987 \\
1989 \\
1994 \\
2010 \\
2013 \\
2014\end{array}$ & $\begin{array}{l}1985 \\
1987 \\
1989 \\
1994 \\
1997 \\
2000 \\
2001 \\
2002\end{array}$ & $\begin{array}{l}1983 \\
1999 \\
2003 \\
2009 \\
2010 \\
2013 \\
2014\end{array}$ \\
\hline Farah & - & 2001 & $\begin{array}{l}1979 \\
1987 \\
2000\end{array}$ & 2001 & 1987 & $\begin{array}{l}1979 \\
2000\end{array}$ & 2001 & 1987 & $\begin{array}{l}1979 \\
2000\end{array}$ & 2001 & 1987 & $\begin{array}{l}1979 \\
1980 \\
1983 \\
1985 \\
1994 \\
2000 \\
2002 \\
2003 \\
2004\end{array}$ & $\begin{array}{l}1979 \\
1987 \\
2000 \\
2001 \\
2002 \\
2003 \\
2004 \\
2012\end{array}$ & $\begin{array}{l}1983 \\
1985 \\
1994 \\
2006 \\
2008 \\
2010 \\
2013\end{array}$ \\
\hline Adraskan & 2001 & 1994 & $\begin{array}{l}1985 \\
1992 \\
1995 \\
2000\end{array}$ & $\begin{array}{l}1994 \\
2001\end{array}$ & - & $\begin{array}{l}1985 \\
1992 \\
1995\end{array}$ & $\begin{array}{l}1994 \\
2001\end{array}$ & - & $\begin{array}{l}1985 \\
1992 \\
1995 \\
2000\end{array}$ & 2001 & 1994 & $\begin{array}{l}1985 \\
1990 \\
1992 \\
1994 \\
1995 \\
1997 \\
2000 \\
2006 \\
2008 \\
2011 \\
2014\end{array}$ & $\begin{array}{l}1985 \\
1992 \\
1994 \\
1995 \\
1997 \\
2000 \\
2001 \\
2008\end{array}$ & $\begin{array}{l}1990 \\
1998 \\
2004 \\
2006 \\
2011 \\
2014 \\
2015\end{array}$ \\
\hline Gardandiwal & 2001 & 2000 & $\begin{array}{l}1985 \\
1998 \\
1999 \\
2002 \\
2003 \\
2004 \\
2012\end{array}$ & $\begin{array}{l}2000 \\
2001\end{array}$ & - & $\begin{array}{l}1985 \\
1998 \\
1999 \\
2002 \\
2003 \\
2004 \\
2012\end{array}$ & $\begin{array}{l}2000 \\
2001\end{array}$ & - & $\begin{array}{l}1985 \\
1998 \\
1999 \\
2002 \\
2003 \\
2004 \\
2012\end{array}$ & - & 2001 & $\begin{array}{l}1985 \\
1993 \\
1998 \\
1999 \\
2000 \\
2002 \\
2003 \\
2004 \\
2012\end{array}$ & $\begin{array}{l}1985 \\
1998 \\
2000 \\
2001 \\
2002 \\
2003 \\
2004 \\
2012\end{array}$ & $\begin{array}{l}1990 \\
1993 \\
1999 \\
2006 \\
2010 \\
2011 \\
2014\end{array}$ \\
\hline
\end{tabular}

According to Table 6, the log-SPI and the gamma-SPI produce almost the same drought predictions while the normal-SPI predicts the extreme drought year of 2001 as the severe drought at Lashkargah and Farah stations. At Gardandiwal station, all the methods predict drought years from 1998 to 2004 (Table 6). The PN method predicts the extreme drought year of 2001 as the severe drought only at Gardandiwal station. The Asia-Pacific Network for Global Change Research [16] states the worst drought year in its recorded history of Afghanistan as 2001, which is predicted by the log-SPI and the gamma-SPI for all the stations. 
As opposed to the SPI methods, the PN produces more moderate drought years in 1980s and early 2010s at Laskargah, 1980s and early 2000s at Farah, 1990s, 2000s and 2010s at Adraskan and 1990s and early 2000s at Gardandiwal stations. As opposed to the other methods, the Deciles index predicts many extreme and severe drought years at the four stations (Table 6). The PN and Deciles indices predict, in general, more drought years. For example; for Adraskan station, while each SPI method, in total, makes 6 drought predictions, this number is 13 for the PN and 15 for the Deciles (Table 6).

\section{CONCLUSIONS}

This study explores the performances of five widely employed drought indices (the normalSPI, the log-SPI, the gamma-SPI, the PN, and the Deciles) at four stations of Helmand River Basin in Afghanistan to find the appropriate indices for monitoring the drought in the basin.

The following conclusions can be drawn from the Helmand River Basin drought analysis:

1) Although the five DI methods provide almost the same results for Lashkargah, Farah, Adraskan, and Gardandiwal stations of Helmand River Basin, the normalSPI could not predict the extreme drought year of $2001([14,15,16])$ at two stations and the PN at one station.

2) More droughts are experienced at the stations from late 1990 s to early $2000 \mathrm{~s}$ with the extreme drought condition in 2001, confirming the reported worst drought in the region $([14,15,16])$.

3) According to the Deciles drought index, when precipitation is less than 60.2 $\mathrm{mm} /$ year, $79.6 \mathrm{~mm} /$ year, $144.6 \mathrm{~mm} /$ year, and $224.9 \mathrm{~mm} /$ year the extreme drought occurs in Lashkargah, Farah, Adraskan, and Gardandiwal stations, respectively.

4) The Deciles method produces too many extreme and severe droughts, most of which are not predicted by the other four indices.

5) The historical extreme year of 2001 at all the stations is captured by the log-SPI and the gamma-SPI methods.

6) The PN and Deciles indices, in general, predict more drought occurrences as opposed to the SPI methods (almost twice of the SPI methods).

7) Based upon above conclusions, the log-SPI and the gamma-SPI can be recommended as the drought monitoring and assessment methods for Helmand River Basin in Afghanistan.

\section{Acknowledgments}

The authors thank the Ministry of Energy and Water of Afghanistan for providing the meteorological and hydrological data used in this study. 


\section{Declarations}

Funding Not applicable

Conflicts of interest None

Availability of data and material

The data that support the findings of this study may be available from the Ministry of Energy and Water of Afghanistan, upon request.

\section{Code availability Not applicable}

Ethical Approval Not applicable

Consent to Participate Not applicable

\section{Authors' contributions}

M.Musa Alami: Carried out all the data collections and model applications and contributed on the writting of the paper.

Gokmen Tayfur: Discussed the application problems and modelling tools, advised the student during the research, and wrote the paper.

\section{References}

[1] Zarei A. R., Moghime M. M, and Mahmodi M. R, 2015. Parametric and NonParametric Trend of Drought in Arid and Semi-Arid Regions Using RDI Index, Water Resource and Management, 30, 5479-5500.

[2] Sirdas S., and Sen Z., 2003. Spatio-temporal drought analysis in the Tarakya region, Turkey, Hydrological Sciences Journal, 48(5), 809-819.

[3] Yacoub E., and Tayfur G., 2017. Evaluation and Assessment of Meteorological Drought by Different Methods in Tazara Region, Mauritania, Water Resource and Management, DOI: 10.1007/s11269-016-1510-8.

[4] Tsakiris, G., \& Vangelis, H., 2005. 'Establishing a drought index incorporating evapotranspiration.’ European Water, 9(10), 3-11.

[5] Bazrahshan, J. and Hejabi, S. (2018). 'A Non-Stationary Reconnaissance Drought Index (NRDI) for Drought Monitoring in a Changing Climate.' Water Resources Management, 32:2611-2624, https://doi.org/10.1007/s11269-018-1947-z

[6] Wang, L., Yua, H., Yang, M., Yang, R., Gao, R. and Wang, Y. (2019). 'A drought index: The standardized precipitation evapotranspiration runoff index.' Journal of Hydrology, JH 2019, 651-668.

[7] Mishra, A.K. and Singh, V.P. (2010). 'Drought modelling- A review.' Journal of Hydrology, 403, 157-175. 
[8] Eslamian, S.Askari, KOA, Singh, VP, Dalezios, NR, GHane, M., Yihdego, Y. and Matouq, M. (2017). 'A Review of Drought Indices.' International Journal of Constructive Research in Civil Engineering (IJCRCE), Volume 3, Issue 4, 2017, PP 48-66

[9] Bulut, M. and Yilmaz, T. 2016. 'Türkiye'deki 2007 ve 2013 yılı kuraklıklarının NOAH hidrolojik Modeli ile incelenmesi.’ Teknik Dergi, 27(4), 7619 - 7634.

[10] Keskiner, A.D., Cetin, M., Simsek, M. and Akin, S. 2020. 'Kuraklık riski altındaki havzalarda gölet haznelerinin tasarımı: Seyhan Havzasında Bir Uygulama.' Teknik Dergi, 31(5), $10189-10210$.

[11] Dikici, M. and Aksel, M. 2021. 'Evaluation of two vegetation indices (NDVI and VCI) over Asi Basin in Turkey.' Teknik Dergi, 32(4) (in press).

[12] Mehr, A.D., Safari, M.J.S. and Nourani, V. 2021. 'Wavelet packet-genetic programming: A new model for meteorological drought hindcasting.' Teknik Dergi, 32(4) (in press).

[13] Dikbas, F. and Bacanli, U.G. 2021. 'Detecting drought variability by using twodimensional correlation analysis.' Teknik Dergi, 32(4), (in press).

[14] Ahmad, M., and Wasiq, M., 2004. Water resources development in Northern Afghanistan and its implications for Amu Darya Basin (No. 36). World Bank Publications.

[15] Miyan, M. A., 2015. Droughts in Asian Least Developed Countries: Vulnerability and sustainability. Weather and Climate Extremes, 7, 8-23.

[16] APN, 2015. An International Geosphere-Biosphere Programme Synthesis Theme on Global Environment Change and Sustainable Development: Needs of Least Developed Countries. A project report by Asia-Pacific Network for Global Change Research, 1617.

[17] Ashraf M., and Routray J. K., 2015. Spatio-Temporal Characteristics of Precipitation and Drought in Balochistan Province, Pakistan, Nat Hazards, 77, 229-254.

[18] Morid S., Smakhtin V., and Moghaddasi M., 2006. Comparison of Seven Meteorological Indices for Drought Monitoring in Iran, International Journal of Climatology, 26, 971-985.

[19] Broshears, R.E., Akbari, M.A., Chornack, M.P., Mueller, D.K., and Ruddy, B.C., 2005. Inventory of ground-water resources in the Kabul Basin, Afghanistan: U.S. Geological Survey Scientific Investigations Report 2005-5090.

[20] Wolf, A. T., Natharius, J. A., Danielson, J. J., Ward, B. S., and Pender, J. K., 1999. International River Basins of the World. International Journal of Water Resources Development, 15(4), 387-427.

[21] Thomas, V., Azizi, M. A., and Behzad, K., 2016. Developing transboundary water resources: What perspectives for cooperation between Afghanistan, Iran and Pakistan? Afghanistan Research and Evaluation Unit, Case Study. 
[22] Goes, B. J. M., Howarth, S. E., Wardlaw, R. B., Hancock, I. R., and Parajuli, U. N., 2015. Integrated wate resources management in an insecure river basin: a case study of Helmand River Basin, Afghanistan. International Journal of Water Resources Development, 32(1), 3-25.

[23] Mckee TB., Doesken NJ., and Kleist J., 1993. The relationship of drought frequency and duration to time scales. Proceedings of the 8th Conference on Applied Climatology, 1993. American Meteorological Society Boston, MA, USA, 179-18.

[24] Cacciamani C., Morgillo A., Marchesi S., and Pavan V., 2007. Monitoring and forecasting drought on a regional scale: Emilia-Romagna region, Methods and Tools for Drought Analysis and Management, Springer, 29-48.

[25] Barua S., Ng A., Perera B., 2010. Comparative Evaluation of Drought Indexes: Case Study on the Yarra River Catchment in Australia, Water Resour Plan Manag, 137, 215226.

[26] Angelidis P., Maris F., Kotsovinos N., Hrissanthou V., 2012. Computation of Drought Index SPI with Alternative Distribution Functions, Water Resources Management, 26(9), 2453-2473.

[27] Thom HCS., 1958. A note on the gamma distribution, Mon Weather Rev 86:117-122.

[28] Abramowitz M., and Stegun A., eds 1965. Handbook of mathematical formulas, graphs and mathematical tables, Dover Publications Inc, New York.

[29] Hayes M. J., 2006 Drought Indices, Willy Online Library Center. (Online). < https://drought.unl.edu/whatis/indices.htm

[30] Gibbs, W. J., and Maaher, J. V., 1967. Rainfall deciles as drought indicators. Bureau of Meteorology, Bulletin No. 48, Commonwealth of Australia, Melbourne, Australia. 